\title{
NRXN3 Gene
}

National Cancer Institute

\section{Source}

National Cancer Institute. NRXN3 Gene. NCI Thesaurus. Code C113536.

This gene is involved in cell recognition and cell adhesion. 